\title{
The Issue of Survival After Colorectal Liver Metastasis Surgery: Parenchyma Sparing vs. Radicality
}

\author{
ANDRÁS PALKOVICS ${ }^{1}$, ANDRÁS VERECZKEI ${ }^{1}$, KÁROLY NAGY KALMÁR ${ }^{1}$, \\ ANDRÁS FINCSUR ${ }^{2}$, ISVÁN KISS ${ }^{3}$, BALÁZS NÉMETH ${ }^{3}$ and ANDRÁS PAPP ${ }^{1}$ \\ ${ }^{1}$ Department of Surgery, Medical School University of Pécs, Pécs, Hungary; \\ ${ }^{2}$ Department of Pathology, Medical School University of Pécs, Pécs, Hungary; \\ ${ }^{3}$ Department of Public Health Medicine, Medical School University of Pécs, Pécs, Hungary
}

\begin{abstract}
Background/Aim: Nowadays, obtaining optimal surgical margin of the resected metastasis and the parenchyma- sparing surgical technique are a great challenge for hepatic surgeons. The aim of this follow-up study was to investigate the prognostic value of the surgical margin and the parenchyma- sparing liver resection technique. Patients and Methods: We performed a retrospective analysis of the data of 319 patients [123 (36.6\%) female and 196 (61.4\%) male] who had colorectal cancer and underwent surgery to treat colorectal liver metastases in our Department between 2005 and 2014. Results: The most commonly used resection type was the non-anatomic resection (43\%). Multivariate analysis indicated that there was no significant difference in survival $(p=0.473)$ between the microscopically-negative $(R 0)$ and microscopically-positive $(R I)$ resections, as well as between the resection types $(p=0.257)$. Conclusion: Parenchymalsparing non-anatomic resection and spray diathermy on the resection surface of the liver should be applied not only for hemostasis, but also to destroy the area containing possible tumor cells after an RI resection and not to have worse survival outcomes.
\end{abstract}

According to the latest WHO data, the worldwide incidence of colorectal cancer (CRC) is over 1.4 million. With approximately 447,000 newly-diagnosed cases per year, $\mathrm{CRC}$ is the most common gastrointestinal malignancy in Europe $(1,2)$. According to the Global Burden of Cancer Study (GLOBOCAN), CRC was found to be the third most frequently occurring cancer type and the third most common cause of cancer related deaths in Europe (3).

Correspondence to: András Palkovics, Department of Surgery, University of Pécs, Ifjúság Street 13, H-7624, Pécs, Hungary. Tel: +36 72536000, e-mail: palkovics.andras@pte.hu

Key Words: Colorectal liver metastasis, parenchymal sparing liver resection, surgical margin.
The 5-year survival rate of CRC for stages I-III is estimated to be around $71 \%$, however, it is only $13 \%$ in stage IV (4).

More than $50 \%$ of patients suffering from CRC develop liver metastases (CRLM). In $25 \%$ of the patients, synchronous hepatic metastases are present at the time of CRC diagnosis. On the other hand, about $40-50 \%$ of the patients develop metachronous liver metastases after resection of the primary CRC (5-7). According to epidemiological data a new or recrudescent hepatic metastasis is likely to develop in 50-75\% of the patients even after an acceptable liver resection. However, only one-fifth of these metastases are resectable $(8,9)$.

In patients with untreated colorectal liver metastases the estimated median survival reaches only 5-8 months $(10,11)$.

Currently, the most effective therapies for patients with CRLM are: multi-modal chemotherapy, multiple ablation modalities and hepatic resection $(6,12,13)$. Regarding surgical success, the current opinion is that patients with macroscopically-positive surgical margin (R2) have worse survival than patients with microscopically positive surgical margin (R1) and microscopically-negative surgical margin (R0) (14-25). However, the results of the studies investigating the effect of R1 and R0 on survival are controversial.

Recently, the surgical margin and liver parenchyma-sparing technique has become an issue among hepatic surgeons. In the case of CRLM the consensus - since the 1980s - was that the optimal surgical margin is more than $1 \mathrm{~cm}$ (14-17). In contrast, some studies could not reveal any negative effect on survival if the tumor free surgical margins were between 0 to $9 \mathrm{~mm}$ (18-23). In addition, some authors claim that CLRM patients with R1 resection do not have worse survival outcomes than patients with R0 resection (24-27).

The results of the most significant studies investigating this issue are presented in Table I.

Due to improvement in surgical and oncological therapies 5-year survival rate for CLRM patients is increasing, thus the need for repeated surgery becomes higher and higher. 
Table I. Resection margin and survival.

\begin{tabular}{|c|c|c|c|c|c|c|c|}
\hline Author & Year & Country & $\begin{array}{c}\text { Number of } \\
\text { patients }\end{array}$ & $\begin{array}{l}\text { Neoadjuvant } \\
\text { chemotherapy }\end{array}$ & $\begin{array}{c}\text { Adjuvant } \\
\text { chemotherapy }\end{array}$ & $\begin{array}{c}\text { Resection } \\
\text { margin }\end{array}$ & $p$-Value \\
\hline Ekberg et al. & 1986 & Sweden & 72 & No & Yes* & $\begin{array}{l}\text { Significant difference if resection } \\
\text { margin is more than } 10 \mathrm{~mm}\end{array}$ & 0.03 \\
\hline Elias et al. & 1998 & France & 269 & No & Yes* & $\begin{array}{l}\text { Significant difference if resection } \\
\text { margin is more than } 9 \mathrm{~mm}\end{array}$ & 0.001 \\
\hline Kokodu et al. & 2002 & Japan & 63 & NA & NA & $\begin{array}{c}\text { No significant difference if resection } \\
\text { margin is more than } 2 \mathrm{~mm}\end{array}$ & 0.9 \\
\hline Pawlik et al. & 2005 & $\begin{array}{l}\text { Multicenter (USA, } \\
\text { Italy, Switzerland) }\end{array}$ & 557 & No & Yes* & $\begin{array}{c}\text { No significant difference if resection } \\
\text { margin is more than } 1 \mathrm{~mm}\end{array}$ & 0.63 \\
\hline Haas et al. & 2008 & France & 436 & Yes* & Yes* & $\begin{array}{c}\text { No significant difference between } \\
\text { R0 vs. R1 resection }\end{array}$ & 0.27 \\
\hline
\end{tabular}

*Not all patients.

On the other hand, in numerous cases, due to the chemotherapy-induced liver parenchyma injury and the effects of the currently used surgical techniques, patients do not have enough liver volume to provide sufficient liver function. Thus, a repeated resection is frequently contraindicated $(8,9,28)$.

Nowadays, because of these factors some authors suggest to perform parenchyma-sparing surgery to keep as much liver tissue as possible. However, the use of the parenchyma sparing technique sometimes sacrifices R0 resection for keeping more liver volume.

The aim of this follow-up study was to investigate the prognostic value of the surgical margin and parenchymasparing on survival in patients who underwent resection of hepatic CRLM.

\section{Patients and Methods}

The present retrospective analytical study was based on the data of patients with colorectal liver metastases who underwent hepatic surgery between January 2005 and December 2014. All surgeries were performed at the Surgery Clinic of the University of Pécs, Pécs, Hungary.

Data collection was performed by using the hospital's medical database. No patients' rights were violated while acquiring data. The collected data were stored anonymously and were only used for scientific purposes.

Patients with non-CRC metastases, and patients with any other malignancies were excluded. The final database contained the following parameters: age, gender, $\mathrm{T}$ and $\mathrm{N}$ stadium of the primary tumor, type of resection, time of diagnosis of liver metastases, resection of liver metastases, diameter of the largest resected liver metastasis and the time of death.

Preoperative management. Patients were examined with liverspecific three-phase computed tomography (CT), and/or magnetic resonance imaging (MR), and/or 18(FDG)-positron emission

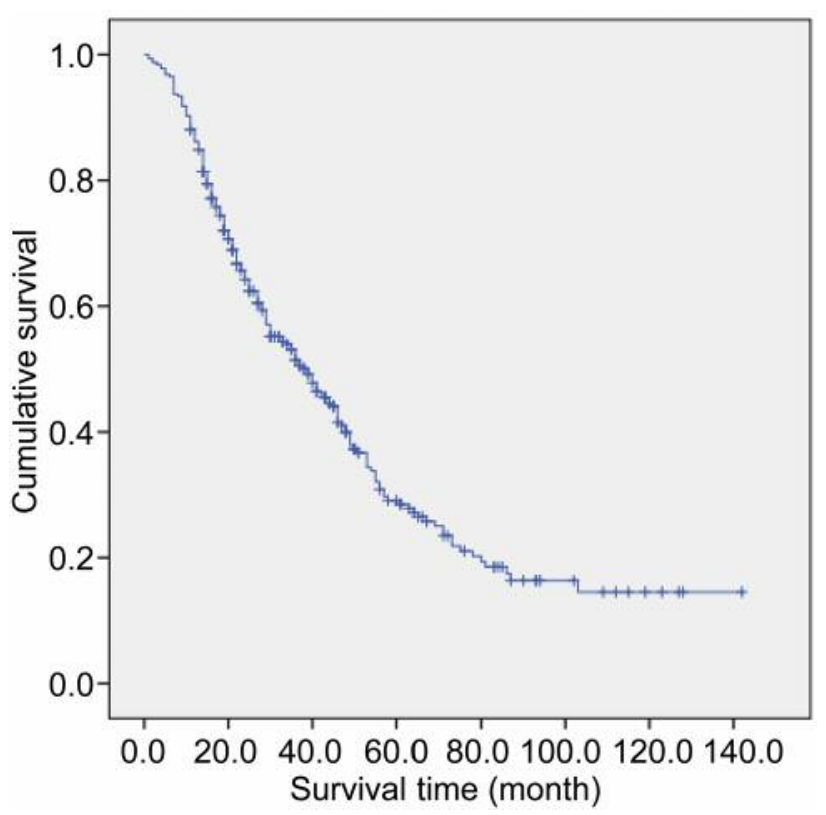

Figure 1. Overall survival from the first liver surgery.

tomography (PET-CT), and/or contrast-enhanced ultrasound, routine blood test and colonoscopy.

All patients have been curatively treated for the primary colon neoplasm and did not have any surgical treatment for extrahepatic metastases. In the case of unresectable hepatic metastases, conversion chemotherapy was administered to allow surgical treatment.

Hepatic resection. After laparotomy abdominal exploration was performed. The number, size, localization, relation with intrahepatic vascular structures of metastases, and the onset of additional lesions were confirmed by palpation and/or intra-operative ultrasound. 
The resection types were: classic lobectomy or parenchyma sparing segmentectomy or non-anatomical metastasectomy. To perform liver parenchymal transection, Kelly clamp-crush technique, ultrasonic dissection (Harmonic Wave, Ethicon EndoSurgery, (Johnson \& Johnson, New Brunswick, NJ, USA), Cavitron Ultrasonic Surgical Aspirator (CUSA), (Covidien, Dublin, Ireland) and electrosurgical pencil (Covidien, Dublin, Ireland) were used.

The major portal veins and bile ducts were ligated with nonabsorbable sutures. In the few cases of major bleeding, intermitted Pringle maneuver was used to reduce hemorrhage.

The cutting surface was coagulated with electrosurgical pencil in "spray mode" to prevent postoperative bleeding in all cases.

Pathological review. All resected specimens underwent histopathological examination. During this, the number, the size, the histological type of metastases, and the resection margin were documented.

Data collection. Medical records and Population Registry Office date were used to perform data collection. Gender, median age, localization of the primary tumor, $\mathrm{T}$ and $\mathrm{N}$ stadium of the primary tumor, type of the liver resection, $\mathrm{R}$ status of the resection surface, and the size of the largest metastases were collected. The survival time referred to the interval between the resection of the primary tumor and the date of death and on the date of hepatic resection and the date of death. Patient data safety was not violated during data collection.

Statistical analysis. Statistical analysis was performed by IBM SPSS Statistics for Windows Version 22 (IBM Corporation, Armonk, NY, USA). Kaplan-Meier method, log rank test, ANOVA regression test and Cox multiple regression model were used for comparing survival to possible prognostic factors. All $p$-values lower than 0.05 were considered as statistically significant.

\section{Results}

Patients. Between January 2005 and December 2014, 528 patients underwent hepatic surgery for secondary liver cancer at our Regional Surgery Center. A total of 209 patients were excluded, because of the following: primary cancer was not CRC, synchronous extra-hepatic metastases were presented, onset of other type of previous malignancies.

Finally, we analyzed the data of 319 patients [123 (36.6\%) female and $196(61.4 \%)$ male] who had colorectal cancer and underwent a surgery to treat colorectal liver metastases. Patients with both synchronous and metachronous liver metastases were included. Fifty-three $(16.7 \%)$ of these patients underwent a second liver surgery and eight $(2.5 \%)$ patients had a third liver surgery. The median follow-up was 47 months. The mean overall survival from the first liver surgery was 51.5 months, with a median of 39 months. The 1-, 3-, and 5-year overall survival rates from the date of hepatic surgery were $85.9 \%, 51.2 \%$, and $29 \%$, respectively. The overall survival curve is shown in Figure 1.

The mean age of the patients at the time of the operation of the primary tumor was $60 \pm 0.67$ years (range $=27-84$ years) and $62 \pm 0.57$ years (range $=28-85$ years) at the time of the liver resection. Mean time between the primary tumor resection and the liver operation was $18.63 \pm 0.97$ months (range=1-104 months). The origin of the primary tumor was the right side of the colon in 72 cases $(22.6 \%)$. The left side of the colon was found to be the origin in 114 cases $(35.7 \%)$. In the remaining 133 cases $(41.7 \%)$ the rectum was identified as the origin of the primary tumor. Overall, 167 patients $(52.4 \%)$ were over 60 years at the time of diagnosis of the primary tumor. The clinical characteristics of the involved patients are shown in Table II.

A total of 106 patients (33.2\%) had synchronous and 213 patients $(66.8 \%)$ had metachronous liver metastases.

Pre-and post-operative chemotherapy. Overall, 228 patients $(71.5 \%)$ received neoadjuvant chemotherapy (FOLFOX, FOLFIRI XELOX, XELIRI) before the first liver surgery. 96 $(30.1 \%)$ of these patients received biological therapy (Avastin, Vectibix, Erbitux) and 152 (64.7\%) patients received adjuvant chemotherapy after the first liver surgery, including the 51 (16\%) patients who received biological therapy.

Clinical characteristics of the involved patients and results of the performed univariate analysis of registered clinical factors are shown in Table II.

No significant differences were found in survival between the gender ( $p=0.667)$, age $(p=0.241)$, location of the primary tumor $(p=0.566)$, time of diagnosis of liver metastases $(p=0.298)$ and type of resection $(p=0.257)$. Patients with unresectable CRC liver metastases had significantly worse $(p<0.001)$ survival. Patients with a large tumor number and size of resected liver metastases had significantly shorter $(p=0.016)$ survival.

The most commonly used resection type was the nonanatomic resection (43\%) and during this surgery sometimes 5-6 metastases were removed. One segment resection was performed in $19.7 \%$ of the cases and two or more segment resections in $27.1 \%$. In the remaining $10.2 \%$ of the cases hepatolobectomy was performed (Figure 2).

Multivariate analysis of clinicopathological factors. The collected factors were tested with multivariate analysis to identify independent factors of survival. Detailed results are shown in Table III.

According to the multivariate analysis there were no significant differences $(p=0.473)$ between the R0 and R1 resection surface on survival. On the other hand, R0 and R2 $(p=0.031)$ and $\mathrm{R} 1$ and $\mathrm{R} 2(p=0.042)$ resections showed significant differences in survival. Patients with macroscopically positive resection surface had significantly shorter survival. According to the univariate analysis, patient with unresectable colorectal liver metastases had significantly shorter $(p=0.001)$ survival.

Age, gender, localization of primary tumor, time of diagnosis of liver metastases and diameter of the largest metastases had no significant effect on survival. 

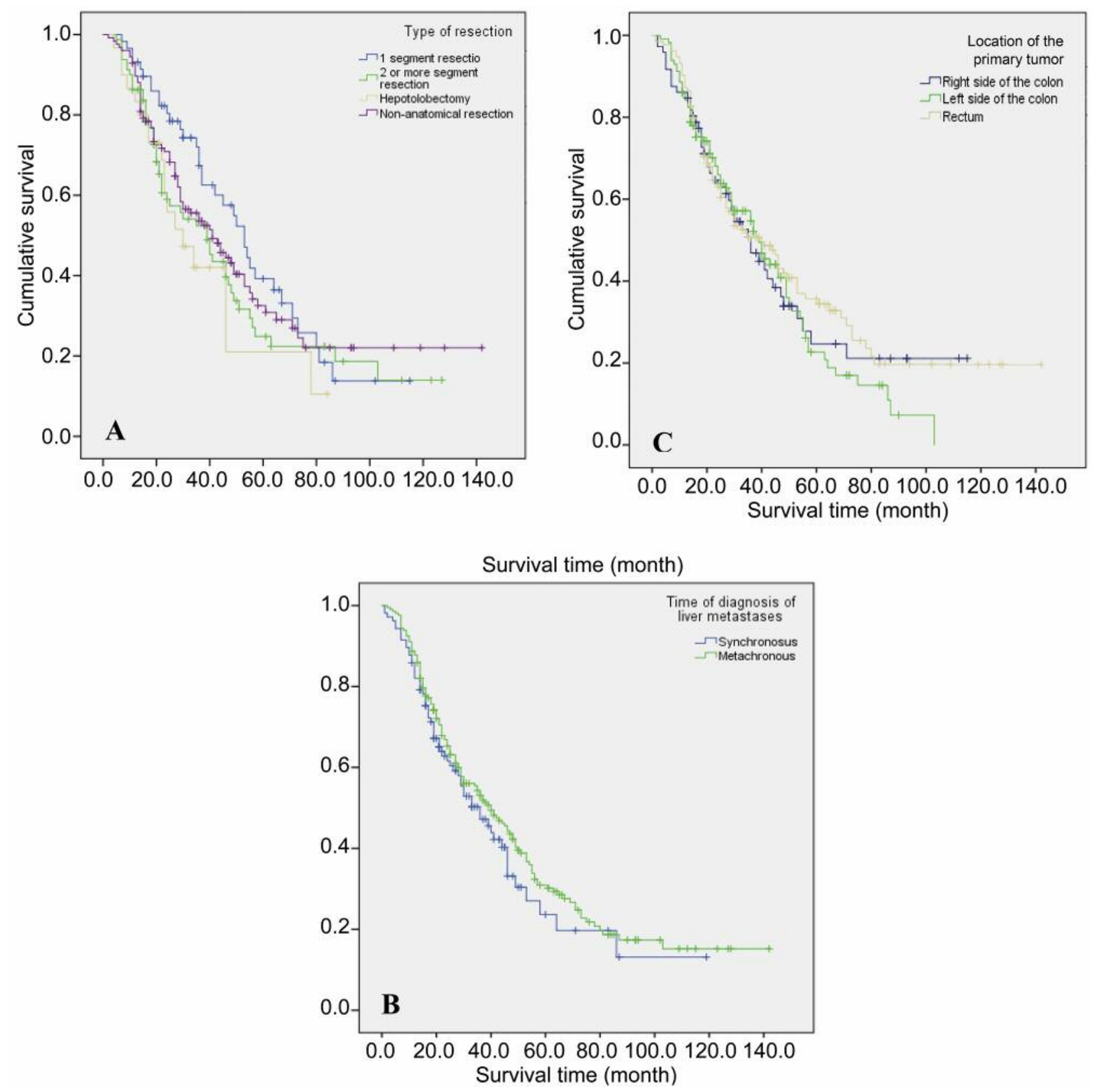

Figure 2. Kaplan-Meier curves of survival (A: type of resection; B: time of diagnosis of liver metastases; C: location of the primary tumor).

The resection radicality. In the case of $207(70.2 \%)$ patients, the first liver resection margin was microscopically negative (R0), 54 (18.3\%) patients' resection was microscopically positive (R1) while the remaining $34(11.5 \%)$ patients' surgery showed macroscopically positive (R2) results.

The median and mean survival of patients with different resection types are shown in Table IV.
There was no significant difference $(p=0.490)$ in survival between the R0 and R1 groups calculated on the interval between hepatic resection to the date of death. Comparing $\mathrm{R} 0$ to $\mathrm{R} 1$, the 1 -year survival was $90.5 \%$ vs. $87.9 \%$, the 2 years survival was $58.4 \%$ vs. $56.4 \%$ and the 5-years survival was $35.8 \%$ vs. $23.2 \%$. However, comparing the survival of $\mathrm{R} 1$ to $\mathrm{R} 2(p=0.037)$ and $\mathrm{R} 0$ to $\mathrm{R} 2$ groups $(p=0.002)$ 
Table II. Clinical characteristics of the involved patients and effects of the investigated clinical factors on survival.

\begin{tabular}{|c|c|c|c|c|}
\hline & No. of patients & $\begin{array}{l}\text { Median survival } \\
\quad \text { (month) }\end{array}$ & $\begin{array}{l}\text { Mean survival } \\
\text { (month) }\end{array}$ & $p$-Value \\
\hline \multicolumn{5}{|l|}{ Gender } \\
\hline Male & 196 & $37(27.2-46.8)^{\mathrm{a}}$ & $48.9(42.6-55.3)^{\mathrm{a}}$ & \\
\hline Female & 123 & $40(28.6-51.4)^{\mathrm{a}}$ & $50.7(41.4-60.1)^{\mathrm{a}}$ & 0.667 \\
\hline \multicolumn{5}{|l|}{ Age } \\
\hline$<60$ & 145 & $42(31.1-52.9)^{\mathrm{a}}$ & $55.0(46.0-64.0)^{\mathrm{a}}$ & \\
\hline$>60$ & 174 & $36(28.8,43.2)^{\mathrm{a}}$ & $45.1(38.9-51.29)^{\mathrm{a}}$ & 0.241 \\
\hline \multicolumn{5}{|l|}{ Location of the primary tumor } \\
\hline Right side of the colon & 72 & $36(24.9-47.0)^{\mathrm{a}}$ & $47.6(37,1-58,1)^{\mathrm{a}}$ & \\
\hline Left side of the colon & 114 & $39(29.0-49.0)^{\mathrm{a}}$ & $42.6(36,6-48,7)^{\mathrm{a}}$ & 0.566 \\
\hline Rectum & 133 & $40(28.3-51.7)^{\mathrm{a}}$ & $55.9(46.3-65.5)^{\mathrm{a}}$ & \\
\hline \multicolumn{5}{|c|}{ Diameter of the largest resected liver metastases } \\
\hline$<5 \mathrm{~cm}$ & 218 & $40(34.1-45.9)^{\mathrm{a}}$ & $52.2(45.7-58.7)^{\mathrm{a}}$ & \\
\hline$>5 \mathrm{~cm}$ & 77 & $30(6.8-53.2)^{\mathrm{a}}$ & $40.7(48.7-58.7)^{\mathrm{a}}$ & 0.147 \\
\hline \multicolumn{5}{|l|}{ Resection of liver metastases } \\
\hline Yes & 295 & $41(35.1-46.9)^{\mathrm{a}}$ & $54.4(48.1-60.6)^{\mathrm{a}}$ & \\
\hline No & 24 & $12(8.2-15.8)^{\mathrm{a}}$ & $13.0(1.8-16.4)^{\mathrm{a}}$ & $<0.001$ \\
\hline \multicolumn{5}{|c|}{ Time of diagnosis of liver metastases } \\
\hline Synchronous & 106 & $36(26.0-46.0)^{\mathrm{a}}$ & $44.5(35.1-54.0)^{\mathrm{a}}$ & \\
\hline Metachronous & 213 & $40(32.3-47.7)^{\mathrm{a}}$ & $53.0(46.1-60.0)^{\mathrm{a}}$ & 0.298 \\
\hline \multicolumn{5}{|l|}{ Type of resection } \\
\hline 1 segment resection & 58 & $53(42.8-63.2)^{\mathrm{a}}$ & $56.0(46.4-65.6)^{\mathrm{a}}$ & \\
\hline 2 or more segment resection & 80 & $39(27.2-50.8)^{\mathrm{a}}$ & $48.7(38.5-59.0)^{\mathrm{a}}$ & \\
\hline Hepatolobectomy & 30 & $30(15.9-44.1)^{\mathrm{a}}$ & $37.8(26.4-49.3)^{\mathrm{a}}$ & \\
\hline Non-anatomical resection & 127 & $41(30.0-52.0)^{\mathrm{a}}$ & $57.4(47.2-67.6)^{\mathrm{a}}$ & 0.257 \\
\hline
\end{tabular}

a95\% Confidence interval.

Table III. Multivariate analysis of prognostic factors.

\begin{tabular}{|c|c|c|c|c|c|c|}
\hline \multirow[b]{2}{*}{ Gender } & \multirow{2}{*}{$\frac{\beta}{0.146}$} & \multirow{2}{*}{$\begin{array}{c}\text { Wald } x^{2} \\
0.433\end{array}$} & \multirow{2}{*}{$\frac{\operatorname{Exp}(\mathrm{B})}{1.157}$} & \multicolumn{2}{|c|}{$95 \% \mathrm{CI}$ for $\operatorname{Exp}(\mathrm{B})$} & \multirow{2}{*}{$\frac{p \text {-Value }}{0.511}$} \\
\hline & & & & 0.759 & 1.789 & \\
\hline Age & -0.003 & 0.061 & 0.097 & 0.097 & 1.018 & 0.805 \\
\hline Time of diagnosis of liver metastases & 0.195 & 0.121 & 1.215 & 0.405 & 3.643 & 0.728 \\
\hline Liver resection & 1.255 & 9.906 & 3.506 & 1.605 & 7.659 & 0.002 \\
\hline Location of primary tumor & 0.176 & 1.446 & 1.192 & 0.895 & 1.587 & 0.229 \\
\hline Resection surface R0 vs. R1 & 0.141 & 0.514 & 1.152 & 0.783 & 1.694 & 0.473 \\
\hline Resection surface R0 vs. R2 & 0.264 & 4.641 & 1.302 & 1.024 & 1.656 & 0.031 \\
\hline Resection surface R1 vs. R2 & 0.533 & 4.135 & 1.704 & 1.019 & 2.850 & 0.042 \\
\hline Diameter of the largest metastases & 0.002 & 0.395 & 1.002 & 0.996 & 1.007 & 0.530 \\
\hline
\end{tabular}

significant differences were found ( $\mathrm{R} 1 v s . \mathrm{R} 2, p=0.037$; R0 $v s$. R2, $p=0.002)$. Seemingly, patients with $\mathrm{R} 2$ resection surface had significantly reduced 5-year survival compared to $\mathrm{R} 0$ or $\mathrm{R} 1$ patients.

\section{Discussion}

According to previous outcome studies, liver resection is the best treatment option for patients suffering from CRC with hepatic metastases $(6,10,11)$. Approximately $50-75 \%$ of these patients develop new or recurrent CRLM after curative liver resection. Only one-fifth of these metastases can be treated surgically $(8,9)$. Several studies were performed to investigate the optimal surgical margin of hepatic resection. In 1986 Ekberg et al. suggested that the optical surgical margin should be more than $1 \mathrm{~cm}$ to achieve significantly higher survival (15). Twelve years later Elias et al. found that the sub-centimeter resection distance is significantly sufficient (22). In the early 2000s both Kokudo et al. and Pawlik et al. found that even 2-5 mm and 1-4 mm is enough to improve survival $(19,20)$. In 2008 Haas et al. were one of the first to publish a follow-up study including nearly 500 
Table IV. The median and mean survival of patients with different resection types.

\begin{tabular}{|c|c|c|c|c|c|c|}
\hline & R0 & $\mathrm{R} 1$ & $\mathrm{R} 1$ & $\mathrm{R} 2$ & R0 & $\mathrm{R} 2$ \\
\hline Median survival (month) & $46(39.3-52.7)^{\mathrm{a}}$ & $43(32.1-53.9)^{\mathrm{a}}$ & $43(32.1-53.9)^{\mathrm{a}}$ & $28(20.7-35.3)^{\mathrm{a}}$ & $46(39.3-52.7)^{\mathrm{a}}$ & $28(20.7-35.3)^{\mathrm{a}}$ \\
\hline Mean survival (month) & $58.5(50.1-66.2)^{\mathrm{a}}$ & $51.5(40-63)^{\mathrm{a}}$ & $51.5(40-63)^{\mathrm{a}}$ & $34.1(24.9-43.3)^{\mathrm{a}}$ & $58.5(50.1-66.2)^{\mathrm{a}}$ & $34.1(24.9-43.3)^{\mathrm{a}}$ \\
\hline \multicolumn{7}{|l|}{ Survival } \\
\hline 1 year & $90.5 \%$ & $87.9 \%$ & $87.9 \%$ & $82.5 \%$ & $90.5 \%$ & $82.5 \%$ \\
\hline 2 years & $58.4 \%$ & $56.4 \%$ & $56.4 \%$ & $29.8 \%$ & $58.4 \%$ & $29.8 \%$ \\
\hline 5 years & $35.8 \%$ & $23.2 \%$ & $23.2 \%$ & $9.9 \%$ & $35.8 \%$ & $9.9 \%$ \\
\hline$p$-Value & \multicolumn{2}{|c|}{0.490} & \multicolumn{2}{|c|}{0.037} & \multicolumn{2}{|c|}{0.002} \\
\hline
\end{tabular}

a95\% Confidence interval.

CRLM resected patients who did not show significant 5-year disease-free survival differences between R1 and R0 resected CRLM patients (25).

In line with Haas et al., this study showed that patients who underwent R1 liver resection did not have significantly worse 5-year survival compared to patients who had R0 resection. This can be explained by the following factors:

1. Multimodal neoadjuvant chemotherapy and adjuvant chemotherapy after hepatic metastasectomy: It has been shown that preoperative chemotherapy does not only convert the initially unresectable disease to resectable (downstagingdownsizing), but is also used to improve the complete resection rate, and increase disease-free survival for resectable CRC $(29,30,31)$.

The multimodal neoadjuvant therapy of CRLM is based on the following cytotoxic agents: fluoropyrimidine [intravenous 5fluorouracil (5-FU) and leucovorin (LV)], oxaliplatin (FOLFOX) and irinotecan (FOLFIRI). The therapy can be expanded with the use of biological targeted agents (bevacizumab, cetuximab, panitumumab) to increase its efficiency (32-34).

There is clear evidence that the adjuvant therapy after hepatic-metastasectomy is capable of reducing cancer reoccurrence and increasing survival (28).

2. "Kelly-clamp crashing technique": with clamp transection of the liver parenchyma (with a mosquito clamp) the surgeon is capable of crushing 2-4 mm parenchyma in the resection line (35-37).

3. Ultrasonic dissectors and other modern parenchyma dissectors (such as harmonic scalpels, or CUSA) which are nowadays used, "dissolves" hepatic tissue on the resection surface as well $(35,38)$. In a non-randomized study by Kim $e t$ $a l$. the use of Harmonic Scalpels was associated with decreased operative time and decreased blood loss and transfusion requirement. However, there was also a significant increase in the incidence of postoperative bile leaks (39). CUSA can be used in cirrhotic as well as non-cirrhotic livers, and is associated with a low blood loss and low risk of bile leak (40).
4. We routinely coagulated the resection surface in "spray mode" with maximum energy to prevent bleeding. Gananadha et al. published an ex vivo investigation, in which the authors presented that the spray diathermia can cause 3-4 mm deep tissue destruction in the liver (41).

In addition to the factors listed above the expected survival is increasing. 5-year survival rates for hepatic colorectal metastases patients have almost doubled since the 1990 s and the need for repeated surgeries is growing too (28).

Both animal and human investigations showed that the liver is capable of remarkable self-regeneration. However, the loss of physiological function seems to be almost directly proportional to the loss of parenchyma (42-44). Furthermore, it is well known that chemotherapy is associated with high incidence of parenchymal injury (45).

Taking this into account it is obvious that the resectable volume is finite and it would be important to remove the minimum amount of useful liver tissue as possible.

Moris $e t$ al. published a systematic review including 2505 CRLM resected patients, which did not show significant 5year overall survival differences between parenchymal sparing and anatomic liver resection in CRLM patients. In agreement with these findings, in our investigation/followup study the type of resection (non-anatomic liver resections, segment resection, or lobectomy) had no significant effect on the 5-year survival.

Vascular R1 resection could be a barrier to make parenchymal sparing liver resection, but based on an observation cohort, vascular R1 resection achieved equivalent outcomes to $\mathrm{R} 0$ resection in the selected cases $(46,47)$.

In short, the present study showed that in the era of modern chemotherapeutics and developed surgical devices the 5-year survival is similar for a patient with R0 and R1 resection, and there seems to be no significant difference between anatomic and non-anatomic liver resection. 


\section{Conclusion}

We suggest that in CRC patients receiving multimodal chemotherapy, the preferred surgical technique should be a parenchymal-sparing non-anatomic resection using modern surgical devices to keep as much liver parenchyma as possible. Furthermore, the resection surface should be coagulated to prevent bleeding and to reduce the number of remaining tumor cells. Of course, the goal is to achieve microscopically-negative surgical margin, but in some cases vascular microscopically-positive surgical margin and vascular R1 resection can be an acceptable result as there seems to be no significant difference in survival.

\section{Conflicts of Interest}

The Authors declare that there is no conflict of interest regarding the publication of this article.

\section{Acknowledgements}

The Authors would like to thank all the administrative employees of our department for their invaluable help. The present scientific contribution is dedicated to the 650th anniversary of the foundation of the University of Pécs, Hungary. Balázs Németh was supported by the ÚNKP-18-3-III New National Excellence Program of the Ministry of Human Capacities, Hungary (http://www.kormany.hu/hu/emberieroforrasok-miniszteriuma). The funder had no role in study design, data collection and analysis, decision to publish, or preparation of the article.

The publication of this manuscript was supported by the "EFOP3.6.3-VEKOP-16-2017-00009" grant.

\section{References}

1 Torre LA, Bray F, Siegel RL, Ferlay J, Lortet-Tieulent J and Jemal A: Global Cancer Statistics, 2012. Ca Cancer J Clin 65: 87-108, 2015

2 Ferlay J, Steliarova-Foucher E, Lortet-Tieulent J, Rosso S, Coebergh JW, Comber H, Forman D and Bray F: Cancer incidence and mortality patterns in Europe: Estimates for 40 countries in 2012. Eur J Cancer 49: 1374-1403, 2013.

3 Ferlay J, Soerjomataram I, Dikshit R, Eser S, Mathers C, Rebelo M, Parkin DM, Forman D and Bray F: Cancer incidence and mortality worldwide: sources, methods and major patterns in GLOBOCAN 2012. Int J Cancer 136(5): E359-386, 2015.

4 Cancer facts and figures 2016 American Cancer Society. Atlanta, GA. http://www.cancer.org (accessed 22.02.2016)

5 Kanas GP, Taylor A, Primrose JN, Langeberg WJ, Kelsh MA, Mowat FS, Alexander DD, Choti MA and Poston G: Survival after liver resection in metastatic colorectal cancer: review and metaanalysis of prognostic factors. Clin Epidemiol 4: 283-301, 2012.

6 Donadon M, Ribero D, Morris-Stiff G, Abdalla EK and Vauthey JN: New paradigm in the management of liver-only metastases from colorectal cancer. Gastrointest Cancer Res 1(1): 20-27, 2007.

7 Inoue Y, Hayashi M, Komeda K, Masubuchi S, Yamamoto M, Yamana H, Kayano H, Shimizu T, Asakuma M, Hirokawa F, Miyamoto Y, Takeshita A, Shibayama Y and Uchiyama K:
Resection margin with anatomic or nonanatomic hepatectomy for liver metastasis from colorectal cancer. J Gastrointest Surg 16: 1171-1180, 2012.

8 Park MS, Yi NJ, Son SY, You T, Suh SW, Choi YR, Kim H, Hong G, KB Lee, Lee KW, Jeong SY, Park KJ, Suh KS and Park JG: Histopathologic factors affecting tumor recurrence after hepatic resection in colorectal liver metastases. Ann Surg Treat Res 87(1): 14-21, 2014.

9 Adair RA, Young AL, Cockbain AJ, Malde D, Prasad KR, Lodge JP and Toogood GJ: Repeat hepatic resection for colorectal liver metastases. Br J Surg 99(9): 1278-1283, 2012.

10 Bengmark S and Hafstrom L: The natural history of primary and secondary malignant tumors of the liver. I. The prognosis for patients with hepatic metastases from colonic and rectal carcinoma by laparotomy. Cancer 23: 198-202, 1969.

11 Simmonds PC: Palliative chemotherapy for advanced colorectal cancer: systematic review and meta-analysis. Colorectal Cancer Collaborative Group. BMJ 321: 531-535, 2000.

12 Saied A, Katz SC and Espat NJ: Regional hepatic therapies: an important component in the management of colorectal cancer liver metastases. Hepatobiliary Surg Nutr 2(2): 97-107, 2013.

13 Van Cutsem E, Nordlinger B, Adam R, Köhne, CH, Pozzo C, Poston G, Ychou M, Rougier P and European Colorectal Metastases Treatment Group: Towards a pan-European consensus on the treatment of patients with colorectal liver metastases. Eur J Cancer 42(14): 2212-2221, 2006.

14 Cady B, Jenkins RL, Steele GD, Lewis WD Jr, Stone MD, McDermott WV, Jessup JM, Bothe A, Lalor P, Lovett EJ, Lavin $\mathrm{P}$ and Linehan DC: Surgical margin in hepatic resection for colorectal metastasis: a critical and improvable determinant of outcome. Ann Surg 227(4): 566-571, 1998.

15 Ekberg H, Tranberg KG, Andersson R, Lundstedt C, Hägerstrand I, Ranstam J and Bengmark S: Determinants of survival in liver resection for colorectal secondaries. Br J Surg 73(9): 727-731, 1986.

16 Shirabe K, Takenaka K, Gion T, Fujiwara Y, Shimada M, Yanaga K, Maeda T, Kajiyama K and Sugimachi K: Analysis of prognostic risk factors in hepatic resection for metastatic colorectal carcinoma with special reference to the surgical margin. Br J Surg 84(8): 1077-1080, 1997.

17 Kato T, Yasui K, Hirai T, Kanemitsu Y, Mori T, Sugihara K, Mochizuki $\mathrm{H}$ and Yamamoto $\mathrm{J}$ : Therapeutic results for hepatic metastasis of colorectal cancer with special reference to effectiveness of hepatectomy: analysis of prognostic factors for 763 cases recorded at 18 institutions. Dis Colon Rectum 46: S22-31, 2003.

18 Are C, Gonen M, Zazzali K, Dematteo RP, Jarnagin WR, Fong Y, Blumgart LH and D'Angelica M: The impact of margins on outcome after hepatic resection for colorectal metastasis. Ann Surg 246(2): 295-300, 2007.

19 Kokudo N, Miki Y, Sugai S, Yanagisawa A, Kato Y, Sakamoto Y, Yamamoto J, Yamaguchi T, Muto T and Makuuchi M: Genetic and histological assessment of surgical margins in resected liver metastases from colorectal carcinoma: minimum surgical margins for successful resection. Arch Surg 137(7): 833-840, 2002.

20 Timothy M, Pawlik TM, Scoggins CR, Zorzi D, Abdalla EK, Andres A, Eng C, Curley SA, Loyer EM, Muratore A, Mentha G, Capussotti L and Vauthey JN: Effect of surgical margin status on survival and site of recurrence after hepatic resection for colorectal metastases. Ann Surg 241(5): 715-722, discussion 722-724, 2005. 
21 Figueras J, Burdio F, Ramos E, Torras J, Llado L, Lopez-Ben S Codina-Barreras A and Mojal S: Effect of subcentimeter nonpositive resection margin on hepatic recurrence in patients undergoing hepatectomy for colorectal liver metastases. Evidences from 663 liver resections. Ann Oncol 18(7): 11901195, 2007.

22 Hamady ZZ, Cameron IC, Wyatt J, Prasad RK, Toogood GJ and Lodge JP: Resection margin in patients undergoing hepatectomy for colorectal liver metastasis: A critical appraisal of the $1 \mathrm{~cm}$ rule. Eur J Surg Oncol 32(5): 557-563, 2006.

23 Elias D, Cavalcanti A, Sabourin JC, Lassau N, Pignon JP, Ducreux M, Coyle C and Lasser P: Resection of liver metastases from colorectal cancer: the real impact of the surgical margin. Eur J Surg Oncol 24(3): 174-179, 1998.

24 Truant S, Séquier C, Leteurtre E, Boleslawski E, Elamrani M, Huet G, Duhamel A, Hebbar M and Pruvot FR: Tumour biology of colorectal liver metastasis is a more important factor in survival than surgical margin clearance in the era of modern chemotherapy regimens. HPB (Oxford) 17(2): 176-184, 2015.

25 De Haas RJ. Wicherts DA, Flores E, Azoulay D, Castaing D and Adam R: R1 resection by necessity for colorectal liver metastases: is it still a contraindication to surgery? Ann Surg 248(4): 626-637, 2008

26 Bodingbauer M, Tamandl D, Schmid K, Plank C, Schima W and Gruenberger T: Size of surgical margin does not influence recurrence rates after curative liver resection for colorectal cancer liver metastases. Br J Surg 94(9): 1133-1138, 2007.

27 Khan SA and Matthews JB: Intraoperative margin re-resection for colorectal cancer liver metastase. Hepatobiliary Surg Nutr 2(2): 108-112, 2013.

28 Misiakos EP, Karidis NP and Kouraklis G: Current treatment for colorectal liver metastases. World J Gastroenterol 17(36): 40674075, 2011.

29 Gustavsson B, Carlsson G, Machover D, Petrelli N, Roth A, Schmoll HJ, Tveit KM and Gibson F: A review of the evolution of systemic chemotherapy in the management of colorectal cancer. Clin Colorectal Cancer 14(1): 1-10, 2015.

30 Takayama T, Makuuchi M, Kubota K, Harihara Y, Hui AM, Sano K, Ijichi M and Hasegawa K: Randomized comparison of ultrasonic vs clamp transection of the liver. Arch Surg 136(8): 922-928, 2001

31 Sasaki Y, Osada S, Matsui S, Imai H, Tanahashi T, Tanaka Y, Matsuhashi N, Okumura N, Yamaguchi K and Yoshida K: Preoperative chemotherapy can change the surgical procedure for hepatectomy in patients with liver metastasis of colorectal cancer. Anticancer Res 35(10): 5485-5489, 2015.

32 Macedo FI and Makarawo T: Colorectal hepatic metastasis: Evolving therapies. World J Hepatol 6(7): 453-463, 2014.

33 Ayez N, Lalmahomed ZS, Eggermont AMM, Ijzermans JNM, de Jonge J, Van Montfort $\mathrm{K}$ and Verhoef C: Outcome of microscopic incomplete resection (R1) of colorectal liver metastases in the era of neoadjuvant chemotherapy. Ann Surg Oncol 19(5): 1618-1627, 2012.

34 Coutinho A and Grothey A: Adjuvant therapy after resection of metastatic colorectal cancer: clear proof of principle in this setting. Oncology (Williston Park) 30(1): 50-51, 53, 2016.
35 Elias D, Bonnet S, Honoré C, Kohneh-Shahri N, Tomasic G, Lassau N, Dromain C and Goere D: Comparison between the minimum margin defined on preoperative imaging and the final surgical margin after hepatectomy for cancer: how to manage it? Ann Surg Oncol 15(3): 777-781, 2008.

36 Lesurtel M, Selzner M, Petrowsky H, McCormack L and Clavien PA: How should transection of the liver be performed? A prospective randomized study in 100 consecutive patients: comparing four different transection strategies. Ann Surg 242(6): 814-822, 2005

37 Kim J, Ahmad SA, Lowy AM, Buell JF, Pennington LJ, Soldano DA, James LE, Matthews JB and Hanto DW: Increased biliary fistulas after liver resection with the harmonic scalpel. Am Surg 69(9): 815-819, 2003.

38 Aragon RJ and Naveenraj L: Solomon: Techniques of hepatic resection. J Gastrointest Oncol 3(1): 28-40, 2012.

39 Poon RT: Current techniques of liver transection. HPB (Oxford) 9(3): 166-173, 2007.

40 Van Cutsem E, Cervantes A, Nordlinger B, Arnold D and ESMO Guidelines Working Group: Metastatic colorectal cancer: ESMO Clinical Practice Guidelines for diagnosis, treatment and followup. Ann Oncol 25: iii1-9, 2014.

41 Gananadha S, Daniel S, Zhao J and Morris DL: An experimental evaluation of ablation devices for the local treatment of the liver resection edge. Eur J Surg Oncol 31(5): 528-532, 2005.

42 Michalopoulos GK: Liver Regeneration J Cell Physiol 213(2): 286-300, 2007.

43 Guglielmi A, Ruzzenente A, Conci S, Valdegamberi A and Iacono C: How much remnant is enough in liver resection? Dig Surg 29(1): 6-17, 2012.

44 Alvarez FA, Claria RS, Oggero $S$ and de Santibañes E: Parenchymal-sparing liver surgery in patients with colorectal carcinoma liver metastases. World J Gastrointest Surg 8(6): 407423, 2016.

45 Robinson SM, Wilson CH, Burt AD, Manas DM and White SA: Chemotherapy-associated liver injury in patients with colorectal liver metastases: a systematic review and meta-analysis. Ann Surg Oncol 19(13): 4287-4299, 2012.

46 Viganò L, Procopio F, Cimino MM, Donadon M, Gatti A, Costa G, Del Fabbro D and Torzilli G: Is tumor detachment from vascular structures equivalent to R0 resection in surgery for colorectal liver metastases? An observational cohort. Ann Surg Oncol 23(4): 1352-1360, 2016.

47 Torzilli G, Adam R, Viganò L, Imai K, Goransky J, Fontana A, Toso C, Majno P and de Santibañes E: Surgery of colorectal liver metastases: pushing the limits. Liver Cancer 6(1): 80-89, 2016.

Received September 27, 2018

Revised October 10, 2018

Accepted October 12, 2018 